\title{
Subprotestic stomatitis caused by incorrect choice of fixed protesis treatment
}

\section{Estomatitis subprotestic causada por una elección incorrecta del tratamiento de protesta fijo}

\author{
ROSADO-VILA, Graciella†, SÁNCHEZ-ÁLVAREZ, Lucía, OROZCO-RODRIGUEZ, Angel Ruben \\ and ORDOÑEZ-CHAVEZ, Guadalupe
}

Universidad Autonoma de Campeche, Faculty of Odontology and Faculty of Nursing, San Francisco de Campeche, México

ID $1^{\text {st }}$ Author: Graciella, Josefa, Rosado-Vila / ORC ID: 0000-0002-8688

ID $1^{\text {st }}$ Coauthor: Lucía, Sánchez-Alvarez / ORC ID: 0000-002-4606-0354

ID $2^{\text {nd }}$ Coauthor: Angel Ruben, Orozco-Rodriguez / ORC ID: 0000-0002-5425-0107

ID $3^{\text {rd }}$ Coauthor: Guadalupe, Ordoñez-Chavez / ORC ID: 0000-0003-4229-7669

DOI: $10.35429 /$ EJE.2019.11.6.28.33

Received September 18, 2019; Accepted December 20, 2019

\begin{abstract}
Abatract
Fixed oral prosthesis as of late has been a very viable option for oral rehabilitation, since these differ from removable prostheses in aesthetic, functional and biological parameters. As a result, they are always preferred by patients. Oral prosthesis' have certain parameters to be fulfilled for its prosthetic indications, such as the number of teeth present in the mouth, the type of occlusion, the level of bone insertion in dental organs that will be used as pillars or stumps, the proportion of root to crown, the absence of periradicular lesions that put us in reserved forecasts for the rehabilitation of dental organs. Under the ideal parameters we will base the final diagnosis for the placement of the correct restoration either in the same prosthetic design, manufactured with an ideal material. The preservation of the residual edge in the edentula area will be respected so that the prosthesis does not play an irritating role within the oral cavity, a relevant factor when placing this type of restorations. A bad adjustment either in individual crowns, fixed bridges can chronically irritate the residual flange resulting in ulcerative, fungal or bacterial lesions. Biological thicknesses, residual flanges must always be respected when designing this type of definitive restorations.
\end{abstract}

Prosthesis, Edentules, Dental Organs

\section{Resumen}

La prótesis bucal fija en la actualidad ha sido una opción muy viable para la rehabilitación bucal, ya que estas difieren de las prótesis removibles en parámetros estéticos, funcionales y biológicos. Dando como resultado que siempre son las preferidas de los pacientes. En la actualidad la prótesis bucal tiene ciertos parámetros a cumplir para su indicación protésicas, tanto como numero de dientes presentes en boca, el tipo de oclusión, Niveles de inserción ósea en órganos dentarios que se usaran como pilares o muñones, la proporción de corona raíz, la ausencia de lesiones periradiculares que nos pongan en pronósticos reservados la rehabilitación de órganos dentarios, bajo los parámetros ideales basaremos el diagnostico final para la colocación de la restauración correcta ya sea en el mismo diseño protésico, fabricado con un material ideal . La preservación del borde residual en la zona edentula se respetara para que la prótesis no juegue un papel irritativo dentro de la cavidad oral factor relevante a la hora de la colocación de este tipo de restauraciones.Un mal ajuste ya sea en coronas individuales, puentes fijos pueden irritar de manera crónica el reborde residual dando como consecuencias lesiones ulcerativas, micóticas o bacterianas. Siempre se deben respetar espesores biológicos, rebordes residuales cuando se diseñan este tipo de restauraciones definitivas.

Protesis fija,Edentulos, Órganos Dentarios

Citation: ROSADO-VILA, Graciella, SÁNCHEZ-ÁLVAREZ, Lucía, OROZCO-RODRIGUEZ, Angel Ruben and ORDOÑEZ-CHAVEZ, Guadalupe. Subprotestic stomatitis caused by incorrect choice of fixed protesis treatment. ECORFAN Journal-Ecuador. 2019. 6-11: 28-33

$\uparrow$ Researcher contributing as first author. 


\section{Introduction}

The absence of one or more teeth involves a deficit in chewing efficiency with both functional and organic consequences, so it is important to avoid their loss and in the worst case try to replace them. The loss of teeth is due to various causes. Periodontal disease and caries are the most frequent ${ }^{1}$, but also the agenesis absence of tooth formation, the lack of eruption, dental inclusion, trauma and tumors may make it necessary to replace them.

By replacing the teeth we also contribute to improving the aesthetics of the patient, since the absence of these, especially the former, produces a sinking of soft tissues and in many people produces an important unsightly effect. Subprothetic stomatitis is considered one of the most frequent pathologies (56\%) that affect the oral tissues of subjects with total or partial removable dentures, 2-3 being more frequently found in the upper jaw2. The high frequency of patients with this pathology could be related to the presence of factors such as the poor hygiene of the prosthesis, the longer use of it, internal and contour irregularities, stability, retention, adaptation and occlusion of the prosthesis.

\section{Causes of Dental Absences}

In addition to trauma (blows), which can cause the loss of one or more teeth, the loss of teeth usually occurs due to two main causes:

A periodontal disease in its most advanced stage destroys the tissue that supports the tooth, so the teeth will end up moving and falling.

It can also be caused by caries so severe that it is not possible to save the tooth with a root canal. In that case, it is necessary to remove the dental piece to relieve the patient's pain and prevent the infection from spreading. Tooth loss, lose teeth.

\section{Consequences of Dental Absences}

A person with dental absences cannot chew food well, so it should be limited to soft foods, and the discomfort that this generates. In addition, with the deterioration of its masticatory function, a whole range of digestive and nutritional problems is exposed.
Changes in chewing mechanics can also cause ear, headache or cervical problems, but today the consequences are mostly psychological. Losing a tooth, especially on the aesthetic front, the visible part of the smile can cause real problems of self-esteem, in a society like today, which values youthful and healthy aspects so much. In fact, several studies of American, Japanese universities and Australians have concluded that the patients who solved their dental absences with osseointegrated implants felt much more confident and were happier in their daily lives than before solving their dental absence.

\section{Treatment of Dental Absences Prosthetically}

Dental absences used to be treated with removable dentures and dental bridges (dentures of a lifetime), but these solutions have clear limitations. These resin prostheses (or metal and resin) adhere poorly to the gum, which causes them to become unfit when the patient eats, talks or laughs. The best treatment for absences are dental implants. They consist of a titanium or zirconium screw, which integrates perfectly into the jaw bone and jaw, on which a crown is placed. With a dental implant, the patient will never notice a difference with a natural tooth. There is nothing that completely replaces a natural tooth, but an osteointegrated implant is as close as possible.

\section{Objective}

Know the different types of pontic used in PBF, the aesthetic, biological and functional advantages of the different types of pontic, as well as the most appropriate indication for your choice.

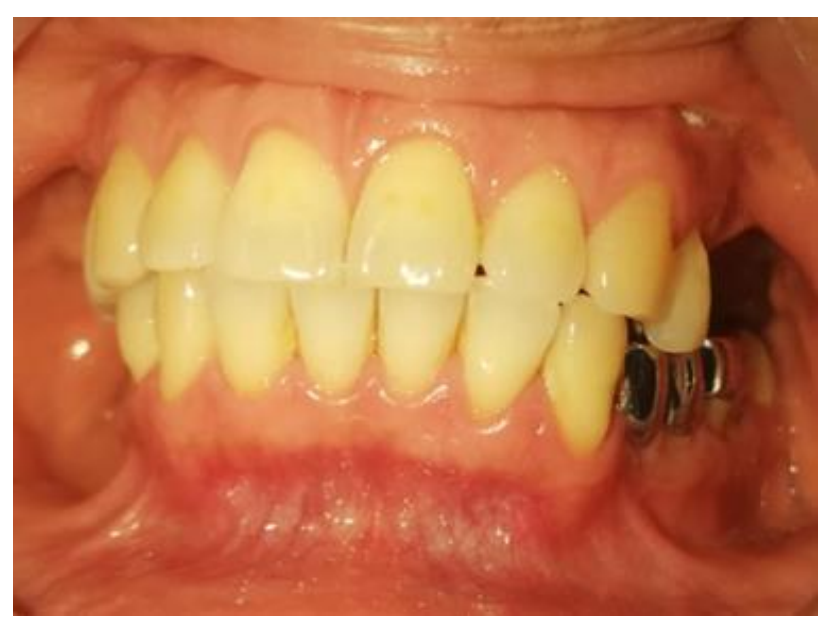

Figure 1

ROSADO-VILA, Graciella, SÁNCHEZ-ÁLVAREZ, Lucía, OROZCORODRIGUEZ, Angel Ruben and ORDOÑEZ-CHAVEZ, Guadalupe Subprotestic stomatitis caused by incorrect choice of fixed protesis treatment. ECORFAN Journal-Ecuador. 2019 


\section{Case Presentation}

This is a 52-year-old male patient, attending clinic 2 of the faculty of dentistry Uac 2019. During the extraoral examination there were no facial alterations. or ganglionic, intraoral examination found various types of restorations including a metal bridge of OD 45-46-47, the patient referred to chewing pain in said restoration, for this reason the prosthesis was removed, when removed found in the residual flange zone a chronic ulcerative lesion approximately $2.5 \mathrm{~cm}$ in diameter below the pontic which was designed in saddle.

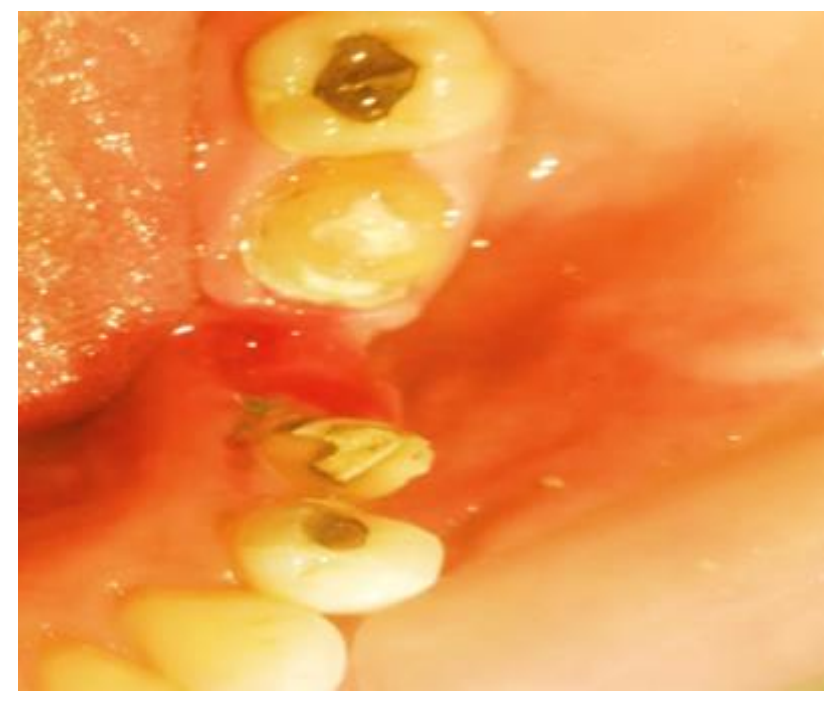

Figure 2

\section{Diagnostic Methods Used Differential Diagnoses}

1. Traumatic Ulcer

2. Subprotic Stomatitis

3. Subprotic Mycosis

\section{Clinical diagnosis}

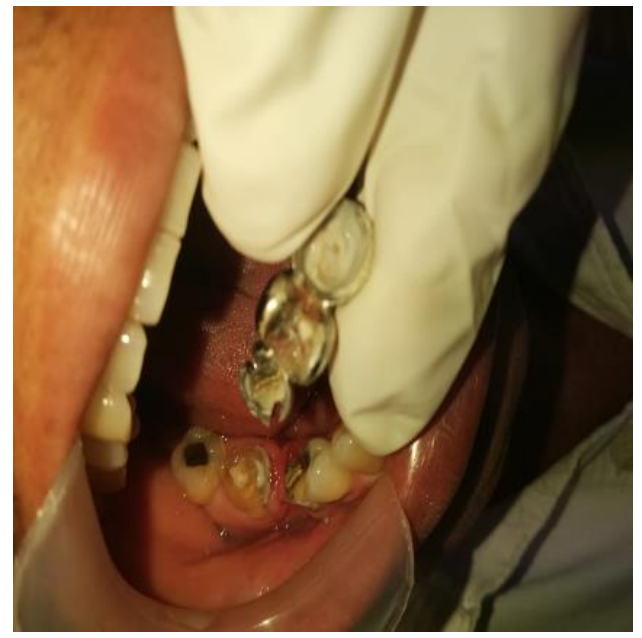

Figure 3

\section{Radiographic Diagnosis}

Facial alterations. or ganglionic, intraoral examination found various types of restorations including a metal bridge of OD 4546-47, the patient referred to chewing pain in said restoration, for this reason the prosthesis was removed, when removed found in the residual flange zone a chronic ulcerative lesion approximately $2.5 \mathrm{~cm}$ in diameter below the pontic which was designed in saddle.

\section{Initial Patient Status}

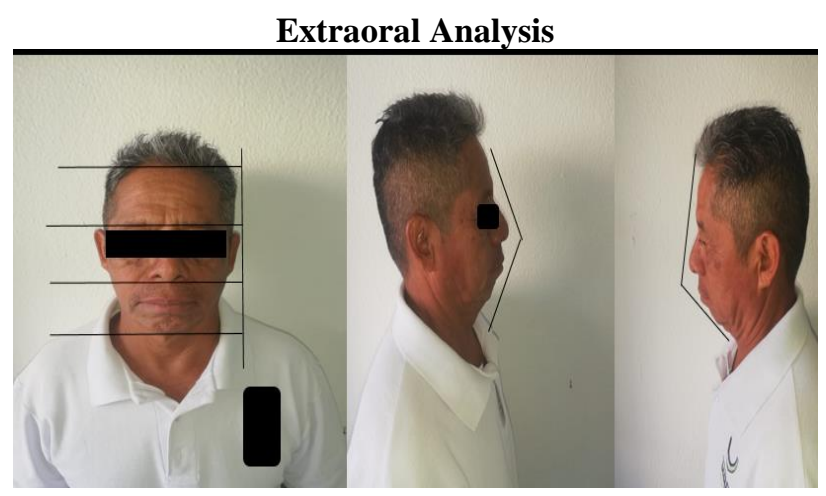

Figure 4

It was observed that the ulcerative lesion was presented by the irritating factor that was the saddle pontics that had been placed since it had direct contact with the antagonist occlusion of the first upper molar causing this dental organ to generate continuous pressure towards the pontic during the masticatory cycles.

\section{Dx: Sub prosthetic stomatitis}

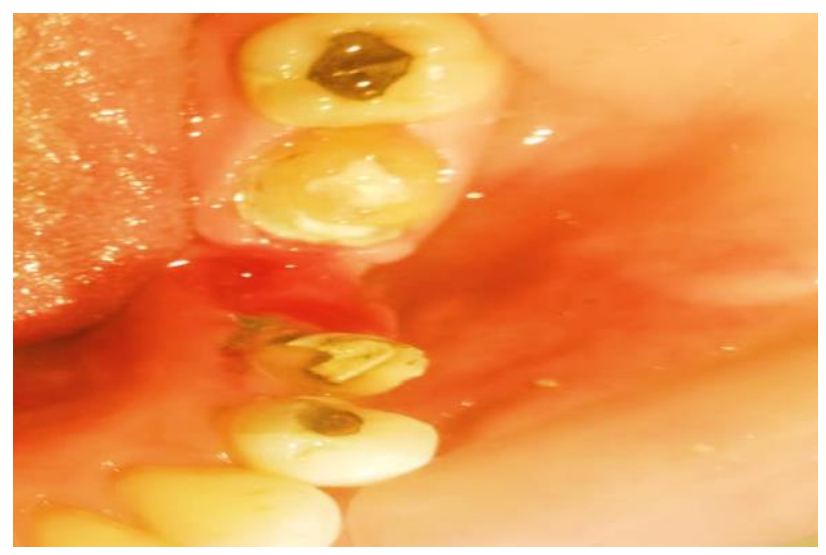

Figure 5

Periapical radiography Pos removal of the fixed bridge from 0D $45-47$. The presence of injury is noted radiolucidal to OD 45 Pulp diagnosis: Coagulation necrosis and in periapical diagnosis: Asymptomatic chronic apical periodontitis.

ROSADO-VILA, Graciella, SÁNCHEZ-ÁLVAREZ, Lucía, OROZCORODRIGUEZ, Angel Ruben and ORDOÑEZ-CHAVEZ, Guadalupe. Subprotestic stomatitis caused by incorrect choice of fixed protesis treatment. ECORFAN Journal-Ecuador. 2019 


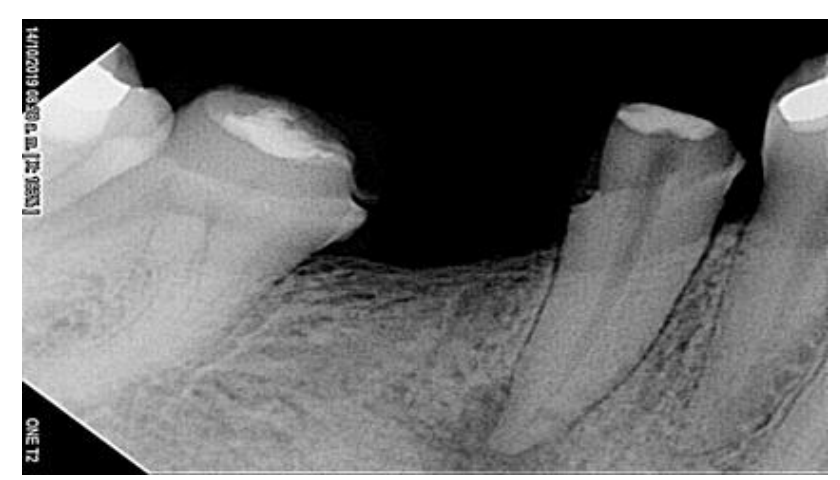

Figure 6

\section{Treatment}

Eliminate the irritating factor permanently and make a fixed oral prosthesis that suits the case. It was decided to make a bridge of 3 units with a hygienic pontic which in this case as a separation greater than $11 \mathrm{~mm}$ from the gingival edge to the antagonist tooth, it was the ideal choice for rehabilitation. It began with the impression of study models and assembly in semi-adjustable articulator for the preparation of a functional biological prototype that best suits the residual edge so as not to irritate the latter. Diagnostic waxing for the functional biological prototype

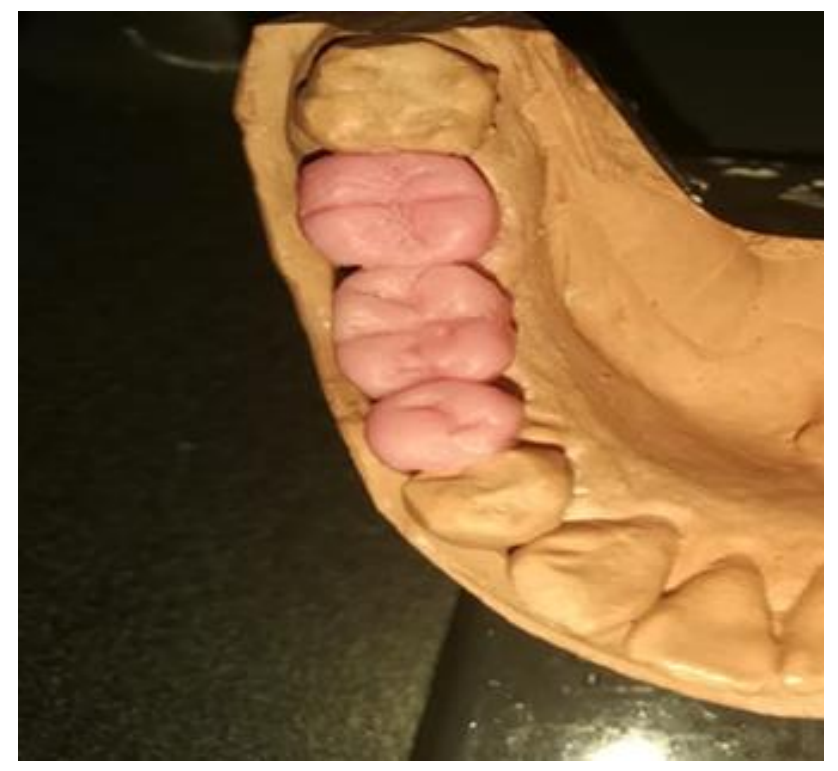

Figure 7

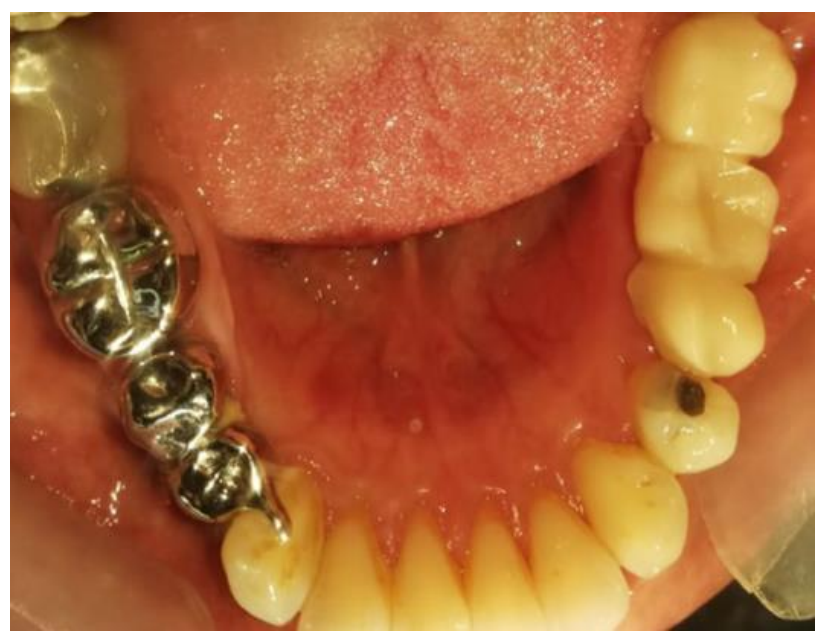

Figure 8

Occlusal adjustment of the PBF with semi-adjustable articulator. Manufacturing of the PBF in acrylic and adjustment in the mouth - 5 days after the removal of the fixed bridge

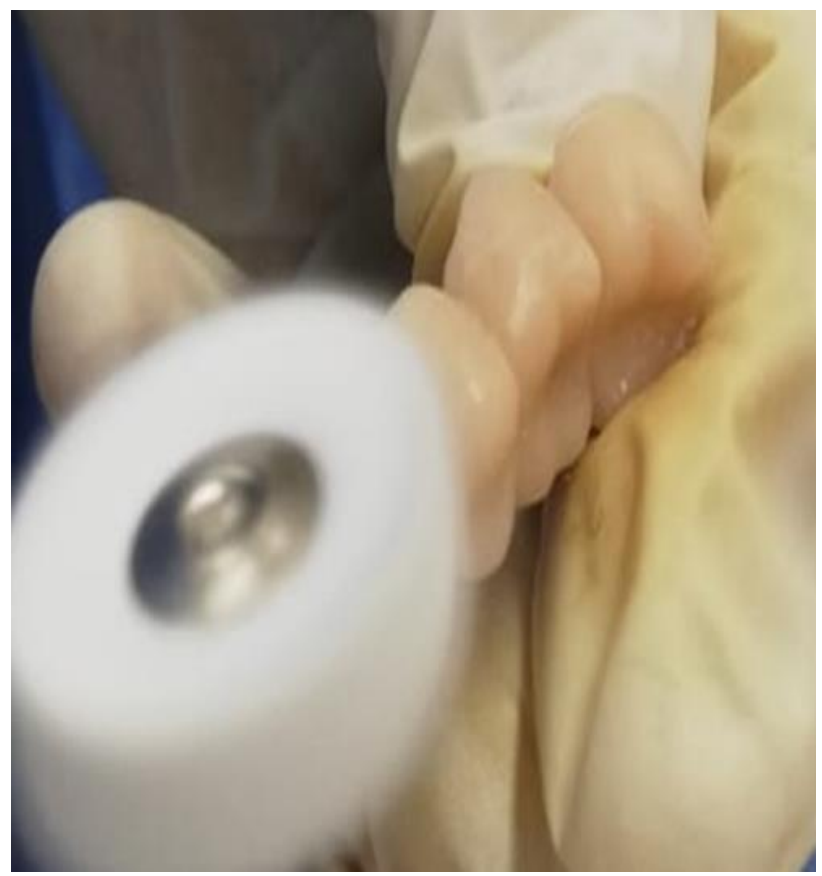

Figure 9

\section{Monitoring}

The patient was inspected 14 days after the installation of his provisional which was fixed to the mouth with a provisional cement that did not irritate the gum adjacent to the pillars and the edentulous space opted for the use of TEMB BOND (VOICO ${ }^{\circledR}$ ) When removing the PBF An improvement in the healing of the ulcerative lesion was observed so that it recovered the continuity of the epithelium by $90 \%$ of its original surface. 


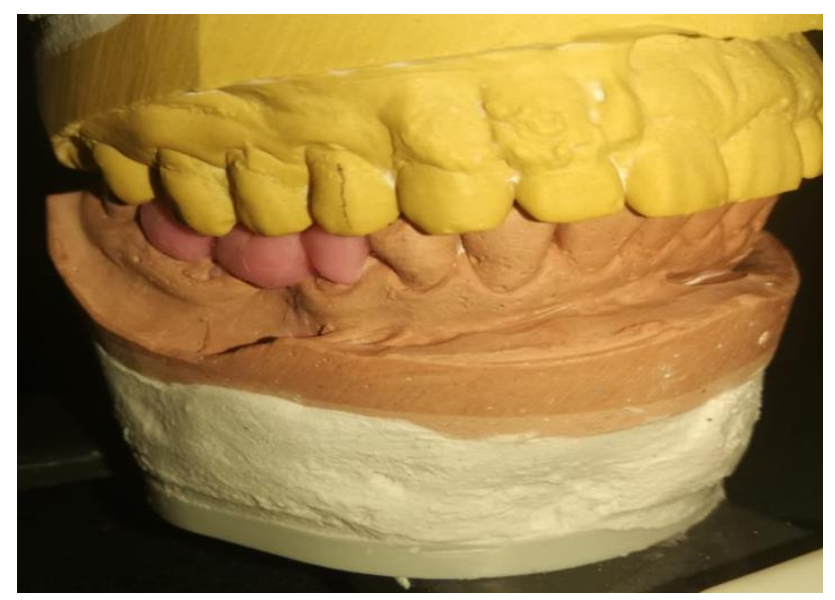

Figure 10

\section{Pbf Manufacturing Protocol.}

1.- A petroleum jelly surface is placed on the bridge pillars 2.- The Speedex ${ }^{\circledR}$ condensation silicone matrix was placed with enough NicTone ${ }^{\circledR}$ color A2 self-healing acrylic in its filamentous phase.3.- The matrix is placed in the bridge area for this to end polymerize. 4.Once polymerized, the acrylic surpluses are trimmed. Carbide stones and diamond discs for polishing with coarse-grained Green stones at $10,000 \mathrm{rpm}$. 5.- The polishing was done with Blankets, Pulecryl and white Spain at 10,000 rpm. PBF installation in mouth

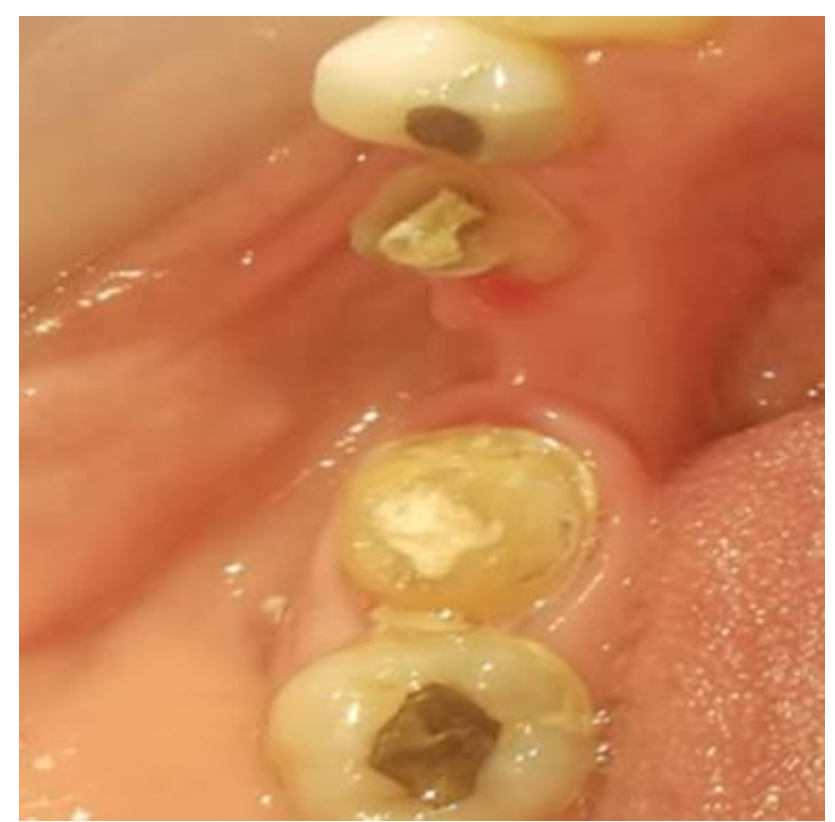

Figure 11

\section{References}

Ayuso-Montero R, Torrent-Collado J, LópezLópez J. Estomatitis protésica:puesta al día. RCOE 2004;9(6):657-662

Becker Curtis (1981) Current theories of crown contour, margin placement and pontic design The Journal of Prosthetic Dentistry 45 ;268-277

Cavazos, Edmund (1968). Tissue response to fixed partial denture pontics. The Journal of Prosthetic Dentistry: 20. 143-153.

Chimenos E. Candidiasis oral en el anciano. En: Bullon P, Velasco E.Odontoestomatología geriátrica. La atención odontológica integral del paciente de edad avanzada. Ed. Smithkline Beecham. Madrid.1996, pág. 229-240

Clayton Joseph (1970) Roughness of pontic materials ands dental plaque The Journal of Prosthetic Dentistry 23;407-411

Crispin, Bruce ( 1979). Tissue response to posterior denture base - type pontics. The Journal of Prosthetic Dentistry: 42. 257-261.

Dylina Tim Contour (1999) determination for ovate pontics The Journal of Prosthetic Dentistry 82:136-142

Howard William (1982). Standards of pontic design.The Journal of Prosthetic Dentistry:47.493-495.

Jiménez-Castellanos E, López M. La prótesis dental en gerontología. En: Bullon P, Velasco E. Odontoestomatología geriátrica. La atención odontológica integral del paciente de edad avanzada. Ed. Smithkline Beecham. Madrid.1996, pág.353-362.

Jiménez-Castellanos E, López M. La prótesis dental en gerontología. En: Bullon P, Velasco E. Odontoestomatología geriátrica. La atención odontológica integral del paciente de edad avanzada. Ed. Smithkline Beecham. Madrid.1996, pág.353-362

Kydd, William (1982) The biologic and mechanical effects of stress on oral mucosa. The Journal of Prosthetic Dentistry 47: 317329. 
Neldelman Charles ( 1970 ) The alveolar ridge in denture and non-denture wearers The Journal of Prosthetic Dentistry 23 ; 265-273

Noguera GA, Fleitas AT. Frecuencia de estomatitis subprotética en pacientes portadores de dentaduras totales. Revista odontológica de los Andes.2006;1:20-2

Parkinson Clayton (1984) Pontic design of posterior fixed partial prostheses is it a microbial misadventure The Journal of Prosthetic Dentistry : 51; 51-54

Perel Morton (1971) Periodontal considerations of crown contours The Journal of Prosthetic Dentistry 26;627-630

Porter Charles (1984) Anterior pontic design The Journal of Prosthetic Dentistry :51;774-184 Stein Sheldon (1966) Pontic-Residual Ridge relationship a research report The Journal of Prosthetic Dentistry 16;251-284 